\title{
TINAGL1 Gene
}

National Cancer Institute

\section{Source}

National Cancer Institute. IINAGL1 Gene. NCI Thesaurus. Code C158391.

This gene may play a role in the regulation of receptor-mediated signaling. 